\title{
Pengaruh Pemberian Pupuk Kompos Solid Terhadap Pertumbuhan Bibit Kakao (Theobroma cacao L) di Polibag
}

\author{
${ }^{1}$ Ida Nursanti, ${ }^{* 1}$ Nasamsir , dan ${ }^{2}$ Ricky Supriyanto \\ ${ }^{1}$ Program Studi Agroteknologi, Fakultas Pertanian Universitas Batanghari \\ ${ }^{2}$ Alumni Program Studi Agroteknologi, Fakultas Pertanian Universitas Batanghari \\ Jl. Slamet Riyadi-Broni, Jambi 36122 Telp +62074160103 \\ *1e-mail korespondensi : nasamsirsamsir@yahoo.co.id
}

\begin{abstract}
Ultisol soil has very low levels of available nutrients and organic matter, so it is necessary to provide input of organic matter to support nutrient supply for cocoa plant growth. The environmental design used was a completely randomized design $(C R D)$ and the treatment design was the application of solid compost consisting of 4 different treatments, namely: s0 : Ultisol soil $3 \mathrm{~kg}$ per polybag (control), s1 : $110 \mathrm{~g}$ solid fertilizer per polybag $+3 \mathrm{~kg}$ of Ultisol soil, s2:135 $\mathrm{g}$ of solid fertilizer per polybag $+3 \mathrm{~kg}$ of Ultisol soil, s3: $160 \mathrm{~g}$ of solid fertilizer per polybag $+3 \mathrm{~kg}$ of Ultisol soil. Data were analyzed using analysis of variance, followed by Duncan's Multiple Distance Test (DNMRT) at the level of 5\%. The results showed that the application of solid compost with different doses gave a significant effect on stem diameter, and had no significant effect on plant height, shoot dry weight, root dry weight, root crown ratio, and quality index.
\end{abstract}

Keywords: solid compost, cocoa, ultisol.

\begin{abstract}
Abstrak. Tanah ultisol memiliki unsur hara tersedia dan bahan organik yang sangat rendah, sehingga diperlukan pemberian input bahan organik untuk mendukung suplay unsur hara guna pertumbuhan tanaman kakao.Penelitian ini bertujuan untuk mengetahui pengaruh pemberian pupuk kompos solid dengan takaran yang berbeda terhadap pertumbuhan bibit kakao. Rancangan lingkungan yang digunakan adalah rancangan acak lengkap (RAL) dan rancangan perlakuan yaitu pemberian pupuk kompos solid yang terdiri dari 4 perlakuan yang berbeda yaitu :s0 : tanah Ultisol $3 \mathrm{~kg}$ per polibag (kontrol), $\mathrm{s} 1: 110 \mathrm{~g}$ pupuk solid per polibag $+3 \mathrm{~kg}$ tanah Ultisol, s2 : $135 \mathrm{~g}$ pupuk solid per polibag $+3 \mathrm{~kg}$ tanah Ultisol, s3 : $160 \mathrm{~g}$ pupuk solid per polibag + $3 \mathrm{~kg}$ tanah Ultisol. Data dianalisis menggunakan analisis ragam, dilanjutkan dengan Uji Jarak Berganda Duncan (DNMRT) pada taraf $\alpha 5 \%$. Hasil penelitian menunjukan bahwa pemberian pupuk kompos solid dengan takaran yang berbeda memberikan pengaruh nyata terhadap diameter batang, dan berpengaruh tidak nyata pada tinggi tanaman, berat kering tajuk, berat kering akar, nisbah tajuk akar, dan indeks kualitas.
\end{abstract}

Kata kunci : pupuk kompos solid, kakao, ultisol.

\section{PENDAHULUAN}

Tanaman kakao (Theobroma cacao L) adalah satu komoditas perkebunan unggulan Indonesia selain karet. Tanaman jenis ini merupakan komoditas perkebunan yang mempunyai dampak yang cukup besar bagi perekonomian negara seperti penyedia lapangan pekerjaan, sumber pendapatan dan devisa negara. Kakao sangat berperan penting dalam meningkatkan perekonomian wilayah dan agroindustry (Muyabin, 2016 ).

Komoditas kakao diharapkan dapat berada pada posisi yang sama dengan komoditas perkebunan lainnya seperti: kopi,karet dan kelapa sawit. Dilihat dari berbagai aspek baik dalam luas areal maupun produksinya kontribusi kakao sangat besar terhadap perekonomian negara sepertimenyediakan bahan baku untuk industri dalam negri yang dapat dimanfaatkan sebagai bahan baku makanan,kosmetik dan farmasi. Dampak terbesar dari perkebunan kakao adalah adanya pembukaan lapangan pekerjaan yang sangat besar bagi penduduk Indonesia mulai dari tahap penanaman, pemeliharaan, pemanenan, pengelolaan, industry, sampai pemasaran (PPKKI, 2004). Dalam jangka waktu yang lama penyediaan kakao dunia diprediksi akan terus mengalami peningkatan dikarenakan banyak negara-negara penghasil utama kakao terus mengalami peningkatan produksi dengan memperluas area tanam. Adanya faktor itu menjadikan konsumen sebagai penentu harga akan cenderung memilih kakao bermutu tinggi dengan harga yang lebih rendah (PPKKI, 2004). Indonesia memiliki potensi untuk menjadi penghasil terbesar produksi kakao di dunia jika dapat mengatasi berbagai macam tantangan yang ada pada perkebunan kakao serta agribisnis kakao harus dikembangkan dan dikelola dengan baik. Indonesia masih memiliki lahan potensial yang cukup besar untuk pengembangan tanaman kakao banyak dilakukan di daerah pegunungan yang ada di Indonesia seperti: Lampung, Bengkulu, Sumatera Selatan, dan Jambi (Muyabin, 2016).

Hilangnya unsur hara dari perakaran secara berlebihan akan menyebabkan merosotnya kesuburan tanah, ketidakmampuan tanah untuk menyediakan unsur hara yang cukup dan seimbang untuk mendukung pertumbuhan dan perkembangan tanaman yang normal menyebabkan produktivitas tanah menjadi sangat rendah. Kerusakan tanah ini terjadi sebagai akibat adanya penguraian bahan organik dan pelapukan mineral dan pencucian unsur hara yang berlangsung dengan cepat (Suripin, 2004). Sebagai pemenuh kebutuhan unsur hara pada tanaman diperlukan penggunaan pupuk organik dan anorganik yang mampu meningkatkan unsur hara pada tanaman kakao. Penggunaan 
pupuk anorganik secara berlebihan dan digunakan dalam jangka waktu yang lama akan menyebabkan menurunnya kesuburan biologis tanah (Ariyanti et al, 2018).

Berdasarkan pada kriteria Ultisol kemampuan dalam menyediakan unsur hara tanah sangat kecil karena Ultisol merupakan tanah yang memiliki kandungan bahan organik yang sedikit sebagai sumber C-Organik. Sumber COrganik merupakan salah satu penyumbang unsur $\mathrm{N}$ yang akan mempengaruhi jumlah kadar N-Total di dalam tanah. Rendahnya kandungan $\mathrm{N}$ didalam tanah diduga karena $\mathrm{N}$ mudah hilang melalui proses pencucian dan penguapan (Darlita,2017). Kation kation yang rendah didalam tanah disebabkan oleh pencucian akibat curah hujan yang tinggi. Pupuk Solid mudah menyatu pada tanah bahkan baunya hampir sama dengan tanah ketika tercampur tanah dan tidak mudah tercuci ataupun menguap, sehingga dapat tersedia secara bertahap sesuai kebutuhan tanaman.

Solid merupakan limbah padat dari hasil pengolahan minyak sawit kasar.Limbah ini dikenal sebagai lumpur sawit di daerah Sumatera, namun solid biasanya sudah dipisahkan dengan cairannya sehingga merupakan limbah padat (Habibi et al., 2014). Solid memiliki kandungan unsur hara seperti N, P, K, Mg dan Ca yang dapat menunjang pertumbuhan tanaman pada tanah PMK. Pemanfaatan solid dalam media tanam berpengaruh nyata terhadap tinggi bibit, diameter batang, jumlah daun, total luas daun, bobot segar dan bobot kering kelapa sawit di pre nursery. Padatan solid memiliki kandungan bahan kering $81,65 \%$ yang di dalamnya terdapat protein kasar $12,63 \%$, serat kasar 9,98\%, lemak kasar 7,12\%, kalsium $0,03 \%$, fosfor $0,003 \%$, hemiselulosa 5,25\%, selulosa 26,35\% dan energi $3454 \mathrm{kkal} / \mathrm{kg}$. Berdasarkan hasil analisis sampel dibeberapa perkebunan besar di Sumatera solid memiliki kandungan N 3,52\%, P 1,97\%, K 0,33\% dan Mg 0,49\%. (Pakpahan, 2015).

Hasil analisis pupuk kompos solid dari Laboratorium Balai Pengkajian Teknologi Pertanian Jambi adalah sebagai berikut : $\mathrm{pH} 5,51$, C-Organik 26,06\%, N Total 2,57\%, P Total 0,10\%, K Total 0,03\%, Kadar Air 62,23\%. Hasil penelitian Nursanti et al.,(2020) pemberian pupuk kompos solid berpengaruh nyata terhadap tinggi tanaman, jumlah tanaman, berat basah daun, jumlah akar, stolon, dan jumlah anakan bibit serai wangi di polibag. Pemberian pupuk kompos solid dengan dosis $135 \mathrm{~g}$ dalam $3 \mathrm{~kg}$ tanah Ultisol menghasilkan peningkatan tinggi 62,22\%, 69,3\%, bobot daun basah 217,8\% jumlah akar dan stolon 57\% dan jumlah anakan 215\% tanaman serai wangi umur 60 hari setelah tanam dibanding tanpa pemberian pupuk kompos solid.

\section{METODE PENELITIAN}

Penelitian ini dilaksanakan di Kebun Pijoan, Universitas Batanghari mulai pada bulan Februari 2021 sampai Juni 2021. Analisis tanah ultisol dan analisis tanah setelah penelitian di analisis di laboratorium Dinas Lingkungan Hidup Provinsi Jambi. Bahan yang digunakan dalam penelitian ini adalah bibit kakao jenis F1 Hibrida dari pembibitan Dinas Perkebunan Desa Pondok Meja Kabupaten Muaro Jambi yang berumur 2 sampai 3 bulan dengan tinggi $40 \mathrm{~cm}$, diameter batang $0,7 \mathrm{~cm}$ dan jumlah daun 10 helai, paranet dan media tanam yang digunakan adalah tanah Ultisol, pupuk kompos solid, air, polibag hitam ukuran $15 \mathrm{~cm}$ x $30 \mathrm{~cm}$ dan bahan lainnya yang diperlukan dalam penelitian. Alat yang digunakan adalah cangkul, parang, pisau, ember, meteran, timbangan analitik, alat tulis, penggaris, kamera, oven dan alat lainnya yang diperlukan dalam penelitian.

Rancangan lingkungan yang akandigunakan dalam penelitian ini adalah rancangan acak lengkap (RAL) satu faktor. Perlakuan yang dicobakan yaitu pupuk kompos solid dengan 4 taraf dosis meliputi :s0 : tanah Ultisol $3 \mathrm{~kg}$ per polibag (kontrol), s1 : $110 \mathrm{~g}$ pupuk solid per polibag $+3 \mathrm{~kg}$ tanah Ultisol, s2 : $135 \mathrm{~g}$ pupuk solid per polibag +3 $\mathrm{kg}$ tanah Ultisol, s3 : $160 \mathrm{~g}$ pupuk solid per polibag $+3 \mathrm{~kg}$ tanah Ultisol. Variabel pengamatan yang diteliti meliputi tinggi tanaman, diameter tanaman, berat kering akar, berat kering tajuk, nisbah tajuk akar, indeks kualitas, dan analisis kimia tanah. Untuk melihat pengaruh perlakuan yang dicobakan, data yang diperoleh dianalisis secara statistika menggunakan analisis varian, kemudian dilanjutkan dengan uji DNMRT pada taraf $\alpha 5 \%$.

\section{HASIL DAN PEMBAHASAN}

Hasil penelitian dan analisis ragam menunjukan bahwa pemberian pupuk kompos solid berbagai takaran memberikan pengaruh nyata terhadap diameter batang, dan berpengaruh tidak nyata terhadap tinggi tanaman, bobot kering tajuk, bobot kering akar, nisbah tajuk akar, dan indeks kualitas.

Tabel 1. Rata-rata Tinggi Tanaman dan Diameter Batang Kakao Dengan Perlakuan Berbagai Takaran Pupuk Kompos Solid.

\begin{tabular}{ccc}
\hline Perlakuan Pupuk Kompos Solid (g polybag) & Tinggi Tanaman $(\mathrm{cm})$ & Diameter Batang $(\mathrm{cm})$ \\
\hline s3 $(160)$ & $58,63 \mathrm{a}$ & $1,51 \mathrm{a}$ \\
s2 (135) & $58,23 \mathrm{a}$ & $1,26 \mathrm{~b}$ \\
s1 (110) & $57,80 \mathrm{a}$ & $1,25 \mathrm{~b}$ \\
s0 (kontrol) & $54,19 \mathrm{a}$ & $1,05 \mathrm{~b}$ \\
\hline
\end{tabular}

Keterangan : Angka-angka yang diikuti oleh huruf kecil yang sama berbeda tidak nyata pada uji lanjut DNMRT $\operatorname{taraf} a=5 \%$ 
Tabel 1 menunjukan bahwa rata-rata tinggi tanaman kakao pada semua perlakuan pupuk kompos solid berbeda tidak nyata. Rata-rata tinggi tanaman tertinggi diperoleh pada perlakuan s3 yaitu : 58,63 cm. Rata-rata diameter batang tanaman kakao pada perlakuan pupuk kompos solid s3 berbeda nyata bila dibanding s0, s2 berbeda tidak nyata dengan s1, s2 dan s1 berbeda nyata dengan s0. Rata-rata diameter batang tanaman tertinggi diperoleh pada perlakuan $\mathrm{s} 3$ sebesar $1,51 \mathrm{~cm}$.

Hasil analisis ragam menunjukan bahwa perlakuan takaran pupuk kompos solid berpengaruh nyata terhadap diameter batang tanaman. Uji lanjut DNMRT pada selang kepercayaan 95\% menunjukan bahwa perlakuan takaran pupuk kompos solid s3 (160g polybag) memberikan hasil rata-rata diameter batang tanaman tertinggi dibanding perlakuan lainya. Pada diameter batang tanaman s3 menunjukan rata-rata diameter batang tanaman tertinggi dengan nilai $1,51 \mathrm{~cm}$. hal ini dikarenakan pemberian pupuk kompos solid dapat memperbaiki sifat fisik, biologi, dan kimia pada tanah. Sifat fisik terlihat pada perubahan struktur media tanam dari berbentuk gumpalan menjadi gembur dan bewarna menjadi pekat dan gelap akibat aktifitas mikroorganisme didalam tanah. Peningkatan kadar N dari $0,28 \%$ menjadi $0,41 \%$, P meningkat dari $0,72 \%$ menjadi $0,94 \%$, K meningkat dari $0,20 \%$ menjadi $0,29 \%$. Struktur tanah yang gembur memungkinkan akar tanaman untuk menyerap unsur hara yang ada pada tanah. Dimana ketersediaan unsur hara didukung oleh pupuk kompos solid mengandung unsur hara sebagai berikut: C-Organik 26,06\%, N Total 2,57\%, P Total 0,10\%, K Total 0,03\%, Kadar Air 62,23\% dengan pH 5,51. Sejalan dengan pendapat Subhan et,al (2009), bahwa perubahan struktur tanah dari berbentuk gumpalan padat menjadi gembur memungkinkan akar tanaman berkembang dengan baik, sehingga memudahkan tanaman dalam menyerap unsur hara yang ada didalam tanah seperti N, P, K berkaitan erat dalam mendukung proses fotosintesis dan produksi fotosintat yang dihasilkan, seperti meningkatkan pertumbuhan tanaman melalui mekanisme pengubahan unsur hara NPK menjadi senyawa organik.

Tabel 2. Rata-rata Berat Kering Tajuk, Berat Kering Akar, Nisbah Tajuk Akar, dan Indeks Kualitas Tanaman Kakao Dengan Perlakuan Berbagai Takaran Pupuk Kompos Solid.

\begin{tabular}{ccccc}
\hline $\begin{array}{c}\text { Perlakuan Pupuk Kompos Solid } \\
\text { (g polybag) }\end{array}$ & Berat Kering Tajuk (g) & Berat Kering Akar (g) & $\begin{array}{c}\text { Nisbah Tajuk } \\
\text { Akar }\end{array}$ & $\begin{array}{c}\text { Indeks } \\
\text { Kualitas }\end{array}$ \\
\hline s3 $(160)$ & $21,78 \mathrm{a}$ & $10,33 \mathrm{a}$ & $2,25 \mathrm{a}$ & $0,66 \mathrm{a}$ \\
s2 $(135)$ & $21,34 \mathrm{a}$ & $10,03 \mathrm{a}$ & $2,11 \mathrm{a}$ & $0,65 \mathrm{a}$ \\
s1 (110) & $18,00 \mathrm{a}$ & $9,55 \mathrm{a}$ & $1,96 \mathrm{a}$ & $0,64 \mathrm{a}$ \\
s0 (kontrol) & $16,56 \mathrm{a}$ & $8,44 \mathrm{a}$ & $1,89 \mathrm{a}$ & \\
\hline
\end{tabular}

Keterangan : Angka-angka yang diikuti oleh huruf kecil yang sama berbeda tidak nyata pada uji lanjut DNMRT $\operatorname{taraf} a=5 \%$

Pada Tabel 2 terlihat bahwa rata-rata berat kering tajuk tanaman kakao pada semua perlakuan pupuk kompos solid berbeda tidak nyata. Rata-rata berat kering tajuk tanaman tertinggi diperoleh pada perlakuan s3 yaitu 21,78 g, berat kering akar tanaman kakao semua perlakuan pupuk kompos solid berbeda tidak nyata, dan berat kering akar tanaman tertinggi diperoleh pada perlakuan s3 yaitu 10,33 g. Rata-rata nisbah tajuk akar tanaman kakao pada semua perlakuan pupuk kompos solid berbeda tidak nyata, sedangkan nisbah tajuk akar tanaman tertinggi diperoleh pada perlakuan s2 yaitu 2,25. Rata-rata indeks kualitas tanaman kakao pada semua perlakuan pupuk kompos solid berbeda tidak nyata, indeks kualitas tanaman tertinggi diperoleh pada perlakuan s2 yaitu : 0,66.

Hasil analisis ragam menunjukkan bahwa indeks kualitas dengan perlakuan berbagai takaran pupuk kompos solid berpengaruh tidak nyata tetapi memiliki nilai indeks kualitas dengan jumlah keseluruhan 0,1 atau lebih dari 0,09 yang berarti semua bibit tanaman kakao sudah bisa dipindahkan kelapangan

Hasil analisis ragam terhadap tinggi, berat kering akar, berat kering tajuk, nisbah tajuk akar, indeks kualitas berpengaruh tidak nyata. Hal ini dapat saja terjadi karena kondisi masing-masing individu tanaman dapat memberikan respon yang berbeda terhadap terhadap pertumbuhan dan perkembangan sel atapun jaringan tanaman. Lakitan (2010) yang menyatakan bahwa pertumbuhan tanaman dapat dipengaruhi oleh faktor genetik yang merupakan substansi pembawa sifat yang diturunkan dari induk ke generasi selanjutnya. Sifat genetik dapat mempengaruhi ciri dan sifat pada tanaman sehingga dapat berpengaruh terhadap pertumbuhan dan perkembangan tanaman. Tanaman yang memiliki sifat genetik yang baik akan tumbuh dan berkembang cepat sesuai dengan priodenya. 
Ida Nursanti, Nasamsir, dan Ricky Supriyanto. Pengaruh Pemberian Pupuk Kompos Solid Terhadap Pertumbuhan Bibit Kakao (Theobroma cacao L) di Polibag

Tabel 3. Hasil analisis sifat tanah $\mathrm{N}$ total, $\mathrm{P}$ total, $\mathrm{K}$ total, dan $\mathrm{C} / \mathrm{N}$ ratio awal sampai akhir penelitian

\begin{tabular}{ccccccc}
\hline \multirow{2}{*}{ No } & \multirow{2}{*}{ Sifat Tanah } & \multirow{2}{*}{ Penelitian Awal } & \multicolumn{3}{c}{ Akhir Penelitian } \\
\cline { 3 - 6 } & N total & $0,28 \% \mathrm{~s}$ & $0,29 \% \mathrm{~s}$ & $0,31 \% \mathrm{~s}$ & $0,33 \% \mathrm{~s}$ & $0,41 \% \mathrm{~s}$ \\
\hline 1. & P total & $0,72 \% \mathrm{~s}$ & $0,73 \% \mathrm{~s}$ & $0,85 \% \mathrm{~s}$ & $0,90 \% \mathrm{~s}$ & $0,94 \% \mathrm{~s}$ \\
2. & K total & $0,20 \% \mathrm{r}$ & $0,22 \% \mathrm{~s}$ & $0,24 \% \mathrm{~s}$ & $0,27 \% \mathrm{~s}$ & $0,29 \% \mathrm{~s}$ \\
\hline 3
\end{tabular}

Ket : r ( rendah ) dan s ( sedang )

Tabel 3 memperlihatkan bahwa hasil analisis tanah terhadap N-total dan P-total tanah sesuia kriteria sifat kimia tanah tidak mengalami peningkatan dari awal penelitian sampai akhir penelitian, sedangkan K-total tanah meningkat dari rendah menjadi sedang. Kondisi ini diduga disebabkan oleh $\mathrm{C} / \mathrm{N}$ ratio pupuk kompos yang digunakan masih tergolong rendah, Sehingga belum dapat berkontribusi terhadap unsur hara atau kadar mineral tanah. Dari hasil perhitungan data kadar tanah $\mathrm{C} / \mathrm{N}$ kompos 10,93 nilai ini mencirikan bahwa pupuk kompos belum maksimal berperan sebagai pupuk organik karena peran $\mathrm{C} / \mathrm{N}$ pupuk kompos solid yang baik antara $15-20$. Salah satu syarat $\mathrm{C} / \mathrm{N}$ rasio yang baik antara lain adalah memiliki nilai $<20$ (Minarsih, 2013).

\section{KESIMPULAN}

Berdasarkan penelitian dan analisis data dapat disimpulkan bahwa pemberian pupuk kompos solid pada tanaman kakao berpengaruh nyata terhadap diameter batang. Diameter batang tertinggi diperoleh dari s3 (160) gram yaitu $1,51 \mathrm{~cm}$ atau meningkat $43,81 \%$ dibanding dengan perlakuan $\mathrm{s} 0$, namun berpengaruh tidak nyata terhadap tinggi tanaman, berat kering tajuk, berat kering akar, nisbah tajuk akar dan indeks kualitas.

\section{DAFTAR PUSTAKA}

Ariyanti, M Suherman, C Rosniawaty, S Fransiscus. 2018. Pengaruh Volume dan frekuensi Air Cucian Beras Terhadap Pertumbuhan Bibit Tanaman Karet (Hevea brasiliensis) Klon GT 1 Jurnal Paspalum. 6 (2) : 114 123.

Darlita RR, B Joy dan R Sudirja. 2017. Analisis Beberapa Sifat Kimia Tanah Terhadap Peningkatan Produksi Kelapa Sawit pada Tanah Pasir di Perkebunan Kelapa Sawit Selangkun. Jurnal Agrikultura 28(1):15-20.

Habibi SN, C Hanum dan J Ginting. 2014. Pertumbuhan Bibit Kelapa Sawit (Elaeis guineensis Jacq) Pada Berbagai Perbandingan Media Tanam Solid Decanter dan Tandan Kosong Kelapa Sawit Pada Sistem Single Stage. Jurnal Online Agroekoteknologi . 2(2): 691 - 701.

Lakitan B. 2010. Dasar-Dasar Fisiologi Tumbuhan. Raja Grafindo Persada. Jakarta.

Minarsih. 2013. Pengaruh Pemberian Kompos Kulit Buah Kakao Sebagai Campuran Media Pembibitan Dan Pupuk NPK 15:15:15 Terhadap Pertumbuhan Bibit Kakao ( Theobroma cacao L )

Muyabin A 2016. Sukses Membudidayakan Cokelat Jawa Barat: Forest. Publishing.

Nursanti I, Nasamsir, Maduwu J T, 2020. Respon Bibit Serai Wangi (Cymbopogon nardus L). Pada Pemberian Pupuk Kompos Solid Dengan Dosis Berbeda di Polibag.Jurnal Media Pertanian. 5(2):65-69.

Pakpahan S. Sampoerno dan S Yoseva.2015. Pemanfaatan Kompos Solid dan Mikroorganisme Selulolitik Dalam Media Tanam Pmk Pada Bibit Kelapa Sawit (Elaeis guineensis Jacq.) di Pembibitan Utama.JOM Faperta 2 (2).

Pusat Penelitian Kopi dan Kakao Indonesia. 2004. Panduan Lengkap Budi Daya. Kakao. Jakarta: Agromedia Pustaka.

Subhan N, Nurtika dan Gunadi N .2009. Respon tanaman tomat terhadap penggunaan pupuk majemuk NPK 15-1515 pada tanah latosol pada musim kemarau. Jurnal Hort. 19(1):40.

Suripin, 2004. Pelestarian Sumberdaya Tanah dan Air. Andi Yogyakarta. 